\title{
Statistical Analysis of Mechanical and Physical Properties of Igneous Rocks
}

\author{
Soran Jabbar H. Salih ${ }^{1^{*}}$ Younis M. Alshkane ${ }^{2}$
}

${ }^{1}$ Department of Civil Engineer, Faculty of Engineering, University of Sulaimni, Al- Sulaimaniyah, Kurdistan Region, Iraq

${ }^{2}$ Department of Civil Engineer, Faculty of Engineering, University of Sulaimni, Al-Sulaimaniyah, Kurdistan Region, Iraq

Email: younis.ali@univsul.edu.iq

*Corresponding author. Email: Soran.hama@univsul.edu.iq

\begin{abstract}
One of the modern finishing materials for building construction is igneous rock. This study was focused on determining the relationships between mechanical and physical properties of igneous rocks. This incorporates point load strength index $\mathrm{Is}_{(50)}$, Unconfined Compression Strength (UCS), flexural strength, poisons ratio, dry density, porosity, Schmidt rebound values and P-wave velocity for a wide range of igneous rocks. The study was performed on data collected from the literature. The results showed that the porosity has a significant negative effect on the dry density of rock samples. The best relationship was observed between modulus of elasticity and temperature with the coefficient of determination $\left(\mathrm{R}^{2}\right)$ of 0.89 ; it means that the temperature had a great influence on the modulus of elasticity so that increasing temperature causes to decrease in modulus of elasticity of igneous rock. In addition, the weakest relationship was observed between flexural strength and p-wave velocity with $\mathrm{R}^{2}$ of 0.42 ; whereas, there was no relationship between UCS and Poisons ratio.
\end{abstract}

Keywords: Igneous rock; mechanical properties; physical properties; modulus of elasticity; temperature.

\section{Introduction}

Solidification of partly molten or molten magma produced from Earth's crust caused to generate igneous rocks. On the word of their formation condition, igneous rocks are classified to two main types, intrusive (plutonic), this type of rock formed from slow cooling of magma deeply inside the earth crust and then start solidification. The second type of igneous rock is volcanic (extrusive) formed from flowing of lava, causing fine 
grained or glassy material as a result of quick cooling at the earth's surface. Main mineral components and grain size are the main characteristics to classified volcanic and plutonic rocks. In most case the maximum mechanical strength comes from unweathered igneous rock(Harker, 2011; McBirney, 1993; Zhou \& Li, 2000). In geotechnical engineering, high mechanical strength generally due to small grained size, while, the alteration of minerals, joints, cavities, and faults cause reduce mechanical strength(Bowen, 1956; Maitre, 1989). Several factors affect the properties of igneous rock, such as the fabric (voids and minerals' arrangement) mineral composition, texture (shape and size of grain), and the condition of the weather (Irfan, 1996). Igneous rocks vary in their petrographic properties, mineralogy, and engineering features for instance shape and size of grain, interlocking degree, and type of contact and composition of the minerals can affect the rock's mechanical properties. The combination of texture and mineral, provide good elastic deformation strength properties for synthetic (fresh) igneous rock (Irfan \& Dearman, 1978; Mendes, Aires-Barros, \& Rodrigues, 1966; Onodera \& Asoka Kumara, 1980; Tuğrul \& Zarif, 1999; Willard \& McWilliams, 1969; Yusof \& Zabidi, 2016). According to the literature the strength of igneous rock increases with increasing fine grain in the rock. In general, the mechanical properties (strength and stiffness) of igneous rock decrease with decreasing grain size (Crawford, DeDontney, Alramahi, \& Ottesen, 2012; Singh, Kainthola, \& Venkatesh, 2012; Tuğrul \& Zarif, 1999). Quartz is one of the main compositions of igneous rock, the more quartz in the rock give higher strength. Meanwhile, if the rock contain feldspar, weakens the rock's strength (Merriam, Rieke III, \& Kim, 1970; Tuğrul \& Zarif, 1999). The composition of igneous rock and mineral crystal frame changes under the influence of temperature, Pores and cracks of igneous rock and its structure changes as well. Micro-cracking occurs with increasing temperature. This is due to the change of the rock's grain size (Rao, Wang, Xie, \& Xie, 2007; Takarli, Prince, \& Siddique, 2008). Thermal damage is mainly caused by minerals' differential thermal expansion(Keshavarz, Pellet, \& Loret, 2010). Various researches have been conducted to deal with the effect of high temperature on the mechanical properties of rock under mechanical loads by utilizing numerical simulation(Jing, 2003; Takarli et al., 2008). Numerous studies have developed empirical equations to determine Young modulus and UCS in rocks depending on point load index $\mathrm{Is}_{(50)}$, Schmidt hammer rebound $(\mathrm{Rn})$ and $\mathrm{P}$-wave velocity $\left(\mathrm{P}_{\mathrm{v}}\right)$ (Çobanoğlu \& Çelik, 2008; Palchik \& Hatzor, 2004; Singh et al., 2012; Thuro, Plinninger, Zah, \& Schutz, 2001). The objectives of this study were to correlate some physical and mechanical properties of Igneous rocks as well as develop a useful empirical equations between igneous rock properties. 


\section{Materials and methods}

\subsection{Data collection}

In this study, the following geotechnical properties were collected from literature: Unconfined Compression Strength (UCS), Flexural strength, P-wave velocity, porosity, Dry density, Modulus of elasticity, Point load strength index, Schmidt hammer and the effect of Temperature on the geotechnical properties of Igneous rocks.

\subsection{Igneous rock properties}

In this study, more than 1000 data points were obtained from literature so as to investigate the relationships between the geotechnical properties of igneous rock. .. All tests have been conducted according to American Society for Testing and Materials (ASTM) and International Society for Rock Mechanics (ISRM). The data were analyzed using linear and nonlinear regression models.

\section{Results and discussion}

\subsection{Unconfined Compressive Strength, UCS (MPa)}

Based on the total of 240 UCS data for Igneous rocks, the range of data was from 6.0 to $212 \mathrm{MPa}$ with a mean value of $93.0 \mathrm{MPa}$, standard deviation of $45 \mathrm{MPa}$ and coefficient of variation COV of $60 \%$ as summarized in Table 1.

\subsection{Tensile strength, $\sigma \mathrm{t}$ (MPa)}

The $\sigma \mathrm{t}$ of previous studies is presented in Table 1. based on the total of 88 ot data for Igneous rocks, the range of data was from 1.5 to $29 \mathrm{MPa}$ with a mean of $13.75 \mathrm{MPa}$, standard deviation of $8.35 \mathrm{MPa}$ and COV of $60 \%$ as summarized in Table 1.

\subsection{P-wave velocity, $\mathrm{Pv}(\mathrm{m} / \mathrm{s})$}

The data of $\mathrm{Pv}$ are collected from other studies as summarized in Table 1. Based on the total of $188 \mathrm{Pv}$ data for Igneous rocks, the data varied from 2300 to $8000 \mathrm{~m} / \mathrm{s}$ with a mean of $4918 \mathrm{~m} / \mathrm{s}$, standard deviation of $1154 \mathrm{~m} / \mathrm{s}$ and COV of $23 \%$ as summarized in Table 1.

\subsection{Porosity, n (\%)}

The statistical analysis of total collected data of $87 \mathrm{n}$ for Igneous rocks collected from the literature presented a variation from 0.14 to $50 \%$ with a mean of $4.8 \%$, standard deviation of $9.80 \%$ and COV of $2.0 .0 \%$ as summarized in Table 1.

\subsection{Dry Unit Weight, $\gamma d r y(k N / m 3)$}


data of 73 were collected from previous studies for $\gamma$ dry for Igneous rocks collected from the literature gave a variation from 1.50 to $28.0 \mathrm{kN} / \mathrm{m} 3$ with a mean of 20.50 $\mathrm{kN} / \mathrm{m} 3$, standard deviation of $9.50 \mathrm{kN} / \mathrm{m} 3$ and COV of $46 \%$ as summarized in Table 1 .

\subsection{Modulus of elasticity, E (GPa)}

A total of 101 data points of $\mathrm{E}$ were collected from literature for Igneous rocks. The range of data was from 2.0 to $13.0 \mathrm{GPa}$ with a mean of $36.25 \mathrm{GPa}$, standard deviation of $19.19 \mathrm{GPa}$ and COV of $53 \%$ as summarized in Table 1.

\subsection{Point load strength index, Is(50) (MPa)}

A data of 119 for Is(50) was collected from other studies for Igneous rocks are presented in Table 1. The range of Is(50) was from 1.0 to $13.0 \mathrm{MPa}$ with a mean value of 4.32 MPa, standard deviation of $2.90 \mathrm{MPa}$ and COV of $67 \%$ as summarized in Table 1.

\subsection{Schmidt hammer, (Rn)}

The $\mathrm{Rn}$ of other research studies is presented in Table 1. The total of 119 data for $\mathrm{Rn}$ of Igneous rocks were obtained from literature. The range of data was from 18 to 72 with a mean of 45.70, standard deviation of 14.25 and COV of $31 \%$ as summarized in Table1.

\subsection{Poisson ratio, $v$}

A total of 61 data of $\mathrm{v}$ for igneous rocks were collected from literature is presented in Table 1. The minimum and maximum values were 0.10 and 0.40 , respectively, with average of 0.25 , standard deviation of 0.064 and COV of $25 \%$ as summarized in Table1.

\subsection{Effect of Temperature change, $T\left(C^{\circ}\right)$}

The effect of temperature on mechanical properties was studied based literature. The minimum and maximum values of $\mathrm{T}$ was 20 to $1130 \mathrm{C}^{\circ}$ out of 19 data from literature and the mean and standard deviation were $278,369 \mathrm{C}^{\circ}$ respectively and COV was $75 \%$ as summarized in Table 1.

\subsection{Relationships between Unconfined Compression Strength and P-wave velocity}

The correlation between UCS and P-wave was investigated using data collected from previous studies using 172 data points using simple regression model, the best relationships between UCS and Pv was a nonlinear model as presented in Fig. 1. The coefficient of determination (R2) and Root Mean Square Error (RMSE) for the relationship were 0.55 and 28.80 respectively. Eq. 1 shows the developed equation. 


$$
. \mathrm{UCS}=0.0008 \mathrm{P}_{\mathrm{v}}^{1.37}
$$

\subsection{Relationships between tensile strength and $P$-wave velocity}

A total of 65 data points were collected from various research studies. The data collected from the literature were quantified using (Eq. 2) as shown in Fig. 2. The change in the $X$ with $\mathrm{Y}$ was represented using relationship shown in Eq. 2. It is clear that as $\mathrm{Pv}$ increases, the tensile strength increases. $\mathrm{R}^{2}$ and RMSE were 0.45 and 5.3 respectively.

$$
\sigma \mathrm{t}=3.138 \exp ^{0.0003 \mathrm{pv}}
$$

\subsection{Relationships between Porosity and P-wave velocity}

Data points of 61 were collected from numerous research studies. The collected data from the studies were calculated using (Eq. 3) as shown in Fig. 3. The change in the X with Y was shown using the relationship (Eq. 3) and the model parameters A and B are summarized in Table 2. It is obvious that increasing of sound velocity decreased porosity. $\mathrm{R}^{2}$ and RMSE for the relationship were 0.69 and 1.55 as summarized in Table 2.

$$
\mathrm{n}=127.42 \exp ^{-9 \mathrm{E}-04 \mathrm{Pv}}
$$

\subsection{Relationships between Modulus of Elasticity and Temperature}

From various research studies 13 data were collected. The collected data from the studies were calculated using (Eq. 4) as shown in Fig.4. The change in the $\mathrm{X}$ with Y was shown using the relationship (Eq. 4) and the model parameters A and B are summarized in Table 2. The change in temperature had a great effect on modulus of elasticity increase of temperature lead to decrease modulus of elasticity. $\mathrm{R}^{2}$ and RMSE were 0.89 and 6.84 as summarized in Table 2.

$$
\mathrm{E}=-0.062 \mathrm{~T}+74.65
$$

\subsection{Relationships between Unconfined Compression Strength and Modulus of Elasticity}

A total of 66 data were collected from various research studies. The collected data from the studies were calculated using (Eq. 5) as shown in Fig.5. The change in the X with Y was shown using the relationship (Eq. 5) and the model parameters A and B are summarized in Table $2 . \mathrm{R}^{2}$ and RMSE were 0.88 and 21.0 respectively as summarized in Table 2. 


$$
\mathrm{UCS}=6.30 \mathrm{E}^{0.7893}
$$

\subsection{Relationships between Unconfined Compression Strength and Point load}

From numerous research studies 129 data were collected. The collected data from the studies were calculated using (Eq. 6) as shown in Fig.6. The change in the $\mathrm{X}$ with Y was shown using the relationship (Eq. 6) and the model parameters A and B are summarized in Table 2. $\mathrm{R}^{2}$ and RMSE for the relationship were 0.53 and 29.40 as summarized in Table3.

$$
\mathrm{UCS}=53.821 \mathrm{I}_{\mathrm{s}}^{0.51}
$$

\subsection{Relationships between Unconfined Compression Strength and Flexural strength}

A total of 89 data were collected from different research studies. The data collected from the literature were quantified using (Eq. 7) as shown in Fig. 7. The change in the X with $\mathrm{Y}$ was represented using relationship (Eq. 7) it can be seen that increased Flexural strength caused to increase Unconfined Compression Strength and the model parameters, A and B are summarized in Table 2. R2 and RMSE for the relationship were 0.63 and 28.6 as summarized in Table 2.

$$
\mathrm{UCS}=4.4877 \sigma \mathrm{t}+23.683
$$

\subsection{Relationships between Unconfined Compression Strength and Schmidt hammer}

119 data were collected from different research studies. The collected data from the studies were calculated using (Eq. 8) as shown in Fig. 8. The change in the $\mathrm{X}$ with $\mathrm{Y}$ was shown using the relationship (Eq. 8) and the model parameters A and B are summarized in Table 2. It is obvious that increasing of Schmidt hammer values lead to increase unconfined Compression Strength. R2 and RMSE for the relationship were 0.73 and 22.25 as summarized in Table 2 .

$$
\mathrm{UCS}=1.4467 \text { Rn1.1066 }
$$

\subsection{Relationships between Dry density and Porosity}

From various research studies 58 data were collected. The collected data from the studies were calculated using (Eq. 9) as shown in Fig.9. The change in the $\mathrm{X}$ with $\mathrm{Y}$ was shown using the relationship (Eq. 5) and the model parameters A and B are summarized 
in Table 2. R2 and RMSE for the relationship were 0.90 and 0.78 as summarized in Table 2.

$$
\gamma \text { dry }=26.97 \exp -0.033 \mathrm{n}
$$

\subsection{Relationships between Unconfined Compression Strength and Poisson's ratio}

From various research studies 61 data were collected. Based on R2 and RMSE no relationship was observed as shown in Fig. 10.

\section{Conclusions}

Based on statistical analysis on data obtained from literature, the following conclusions were drawn:

1. The UCS - Rn relationship was stronger than the UCS-Is ${ }_{(50)}$ Relationship for Igneous rocks.

2. $\mathrm{P}_{\mathrm{v}}$ have a good relationship with $\mathrm{n}$, compared to UCS and $\sigma \mathrm{t}$ based on RMSE and $\mathrm{R}^{2}$.

3. The inverse relationship observed between $n$ and $\gamma$ dry, as well as with $\mathrm{P}_{\mathrm{v}}$ have been proven.

4. Low correlation coefficients were achieved between $\sigma \mathrm{t}$ and $\mathrm{P}_{\mathrm{v}}$, nevertheless good correlation coefficients were trended between UCS and $\sigma \mathrm{t}$.

5. Temptature change $(\mathrm{T})$ have a great effect on UCS, increasing 35 times of $\mathrm{T}$ caused to decrease UCS 35 times.

6. Based on Root Mean Square Error (RMSE) and coefficient of determination $\left(\mathrm{R}^{2}\right)$ values, the acceptable relationships were observed between igneous rock properties.

\section{References:}

Bowen, N. L. (1956). The evolution of the igneous rocks: Dover Publications.

Çobanoğlu, İ., \& Çelik, S. B. (2008). Estimation of uniaxial compressive strength from point load strength, Schmidt hardness and P-wave velocity. Bulletin of Engineering Geology and the Environment, 67(4), 491-498.

Crawford, B., DeDontney, N., Alramahi, B., \& Ottesen, S. (2012). Shear strength anisotropy in fine-grained rocks. Paper presented at the 46th US Rock Mechanics/Geomechanics Symposium.

Harker, A. (2011). The natural history of igneous rocks: Cambridge University Press. 
Irfan, T. (1996). Mineralogy, fabric properties and classification of weathered granites in Hong Kong. Quarterly Journal of Engineering Geology and Hydrogeology, 29(1), $5-35$.

Irfan, T., \& Dearman, W. (1978). Engineering classification and index properties of a weathered granite. Bulletin of the International Association of Engineering Geology-Bulletin de l'Association Internationale de Géologie de l'Ingénieur, 17(1), 79-90.

Jing, L. (2003). A review of techniques, advances and outstanding issues in numerical modelling for rock mechanics and rock engineering. International Journal of Rock Mechanics and Mining Sciences, 40(3), 283-353.

Keshavarz, M., Pellet, F., \& Loret, B. (2010). Damage and changes in mechanical properties of a gabbro thermally loaded up to 1,000 C. Pure and Applied Geophysics, 167(12), 1511-1523.

Maitre, L. (1989). A classification of igneous rocks and glossary of terms. Recommendations of the international union of geological sciences subcommission on the systematics of igneous rocks, 193.

McBirney, A. R. (1993). Igneous petrology: Jones \& Bartlett Learning.

Mendes, F. M., Aires-Barros, L., \& Rodrigues, F. P. (1966). The use of modal analysis in the mechanical characterization of rock masses. Paper presented at the $1 \mathrm{st}$ ISRM Congress.

Merriam, R., Rieke III, H. H., \& Kim, Y. C. (1970). Tensile strength related to mineralogy and texture of some granitic rocks. Engineering Geology, 4(2), 155160.

Onodera, T., \& Asoka Kumara, H. (1980). Relation between texture and mechanical properties of crystalline rocks. Bull Int Assoc Eng Geol, 22, 173-177.

Palchik, V., \& Hatzor, Y. (2004). The influence of porosity on tensile and compressive strength of porous chalks. Rock mechanics and rock engineering, 37(4), 331-341.

Rao, Q.-h., Wang, Z., Xie, H.-f., \& Xie, Q. (2007). Experimental study of mechanical properties of sandstone at high temperature. Journal of Central South University of Technology, 14(1), 478-483.

Singh, T., Kainthola, A., \& Venkatesh, A. (2012). Correlation between point load index and uniaxial compressive strength for different rock types. Rock mechanics and rock engineering, 45(2), 259-264.

Takarli, M., Prince, W., \& Siddique, R. (2008). Damage in granite under heating/cooling cycles and water freeze-thaw condition. International Journal of Rock Mechanics and Mining Sciences, 45(7), 1164-1175. 
Thuro, K., Plinninger, R., Zah, S., \& Schutz, S. (2001). Scale effects in rock strength properties. Part 2: Point load test and point load strength index. Paper presented at the Rock Mechanics-A Challenge for Society.-881 p., Proceedings of the ISRM Regional Symposium Eurock.

Tuğrul, A., \& Zarif, I. (1999). Correlation of mineralogical and textural characteristics with engineering properties of selected granitic rocks from Turkey. Engineering Geology, 51(4), 303-317.

Willard, R., \& McWilliams, J. (1969). Microstructural techniques in the study of physical properties of rock. Paper presented at the International Journal of Rock Mechanics and Mining Sciences \& Geomechanics Abstracts.

Yusof, N., \& Zabidi, H. (2016). Correlation of mineralogical and textural characteristics with engineering properties of granitic rock from Hulu Langat, Selangor. Procedia Chemistry, 19, 975-980.

Zhou, X., \& Li, W. (2000). Origin of Late Mesozoic igneous rocks in Southeastern China: implications for lithosphere subduction and underplating of mafic magmas. Tectonophysics, 326(3-4), 269-287.

\section{Appendices}

Table 1. Statistical Variation of Igneous rock properties

\begin{tabular}{|c|c|c|c|c|c|}
\cline { 2 - 6 } \multicolumn{1}{c|}{} & \multicolumn{5}{c|}{ Igneous Rock } \\
\hline $\begin{array}{c}\text { Statistical } \\
\text { Parameters }\end{array}$ & No. of Data & Range & Mean $(\mu)$ & Std. Deviation $(\sigma)$ & COV $(\%)$ \\
\hline
\end{tabular}


مجلة جمعة كرمياذ $\quad$ Journal of Garmian University

كَوْفارى زانكوّى كَلهرميان

\begin{tabular}{|c|c|c|c|c|c|}
\hline USC (MPa) & 240 & $6.0-212$ & 93.0 & 45.0 & 48 \\
\hline $\begin{array}{c}\text { Flexural } \\
\text { strength(MPa) }\end{array}$ & 88 & $1.50-29$ & 13.75 & 8.35 & 60 \\
\hline $\begin{array}{c}\text { P-wave velocity, } \\
\mathrm{P}_{\mathrm{v}}(\mathrm{m} / \mathrm{s})\end{array}$ & 188 & $2300-8000$ & 4918 & 1154 & 23 \\
\hline Porosity, n(\%) & 87 & $0.14-50.0$ & 4.80 & 9.80 & 2.0 \\
\hline $\begin{array}{c}\text { Dry density, } \gamma_{\text {dry }} \\
\left(\mathrm{kN} / \mathrm{m}^{3}\right)\end{array}$ & 73 & $1.50-28.0$ & 20.50 & 9.50 & 46 \\
\hline $\begin{array}{c}\text { Modulus of } \\
\text { elasticity, (Gpa) }\end{array}$ & 105 & $2.0-75.0$ & 36.25 & 19.19 & 53 \\
\hline $\begin{array}{l}\text { Point load strength } \\
\text { index, } \mathrm{Is}_{(50)}(\mathrm{Mpa})\end{array}$ & 119 & $1.0-13.0$ & 4.32 & 2.90 & 67 \\
\hline $\begin{array}{l}\text { Schmidt hammer } \\
(\mathrm{Rn})\end{array}$ & 119 & $18-72$ & 45.70 & 14.25 & 31 \\
\hline Poisson's ratio, $v$ & 61 & $0.10-0.40$ & 0.25 & 0.064 & 25 \\
\hline $\begin{array}{c}\text { Temperature, } \\
\mathrm{T}\left(\mathrm{C}^{\circ}\right)\end{array}$ & 19 & $20-1130$ & 369 & 278 & 75 \\
\hline
\end{tabular}

Table 2. Model parameters for Expansive soil properties

\begin{tabular}{|c|c|c|c|c|c|c|c|}
\hline $\begin{array}{l}\text { depended Variable } \\
\text { (Y-axis) }\end{array}$ & $\begin{array}{c}\text { In depended } \\
\text { Variable (X-axis) }\end{array}$ & A & B & $\mathrm{R}^{2}$ & RMSE & $\begin{array}{l}\text { No. of } \\
\text { Data }\end{array}$ & $\begin{array}{l}\text { Fig. } \\
\text { No. }\end{array}$ \\
\hline $\begin{array}{c}\text { Unconfined } \\
\text { Compression Strength } \\
\text {,USC }(\mathrm{kPa})\end{array}$ & $\begin{array}{l}\text { P-wave velocity, } \\
\qquad \mathrm{P}_{\mathrm{v}}(\mathrm{m} / \mathrm{s})\end{array}$ & 0.0008 & 1.37 & 0.55 & 28.8 & 172 & Fig.1 \\
\hline $\begin{array}{l}\text { Flexural strength, } \sigma \mathrm{t} \\
(\mathrm{MPa})\end{array}$ & $\begin{array}{c}\text { P-wave velocity, } \\
\mathrm{P}_{\mathrm{v}}(\mathrm{m} / \mathrm{s})\end{array}$ & 3.138 & 0.0003 & 0.45 & 5.30 & 65 & Fig.2 \\
\hline Porosity, n (\%) & $\begin{array}{l}\text { P-wave velocity, } \\
\qquad \mathrm{P}_{\mathrm{v}}(\mathrm{m} / \mathrm{s})\end{array}$ & 127.42 & -0.0009 & 0.69 & 1.55 & 61 & Fig.3 \\
\hline $\begin{array}{l}\text { Modulus of Elasticity, } \\
\text { E (Gpa) }\end{array}$ & $\begin{array}{c}\text { Temperature, } \\
\mathrm{T}(\stackrel{\mathrm{c}}{\mathrm{c}})\end{array}$ & 74.65 & -0.062 & 0.89 & 6.84 & 13 & Fig. 5 \\
\hline $\begin{array}{c}\text { Unconfined } \\
\text { Compression Strength }\end{array}$ & $\begin{array}{l}\text { Modulus of } \\
\text { Elasticity, E }\end{array}$ & 6.30 & 0.7893 & 0.85 & 21.0 & 66 & Fig.4 \\
\hline
\end{tabular}


مجلة جامعة كرمبـاذ Journal of Garmian University كَوْقَارى زانكوّى كَلهرميـان

\begin{tabular}{|c|c|c|c|c|c|c|c|}
\hline ,USC(kPa) & (Gpa) & & & & & & \\
\hline $\begin{array}{c}\text { Unconfined } \\
\text { Compression Strength } \\
\text {,USC }(\mathrm{kPa})\end{array}$ & $\begin{array}{l}\text { Point load, Is }(50) \\
(\mathrm{Mpa})\end{array}$ & 53.821 & 0.51 & 0.56 & 29.40 & 119 & Fig.6 \\
\hline $\begin{array}{c}\text { Unconfined } \\
\text { Compression Strength } \\
\text {,USC }(\mathrm{kPa})\end{array}$ & $\begin{array}{c}\text { Flexural strength, } \\
\text { ot }(\mathrm{MPa})\end{array}$ & 23.68 & 4.49 & 0.63 & 28.60 & 89 & Fig.7 \\
\hline $\begin{array}{c}\text { Unconfined } \\
\text { Compression Strength } \\
\text {,USC }(\mathrm{kPa})\end{array}$ & $\begin{array}{l}\text { Schmidt hammer, } \\
(\mathrm{Rn})\end{array}$ & 1.4467 & 1.1066 & 0.73 & 22.25 & 119 & Fig.8 \\
\hline $\begin{array}{c}\text { Dry density, } \gamma \text { dry } \\
(\mathrm{kN} / \mathrm{m} 3)\end{array}$ & Porosity, $\mathrm{n}$ & 26.97 & -0.033 & 0.90 & 0.78 & 58 & Fig.9 \\
\hline $\begin{array}{c}\text { Unconfined } \\
\text { Compression Strength } \\
\text {,USC }(\mathrm{kPa})\end{array}$ & Poisson's ratio, $v$ & \multicolumn{4}{|c|}{ No relation was observed } & 61 & Fig. 10 \\
\hline
\end{tabular}

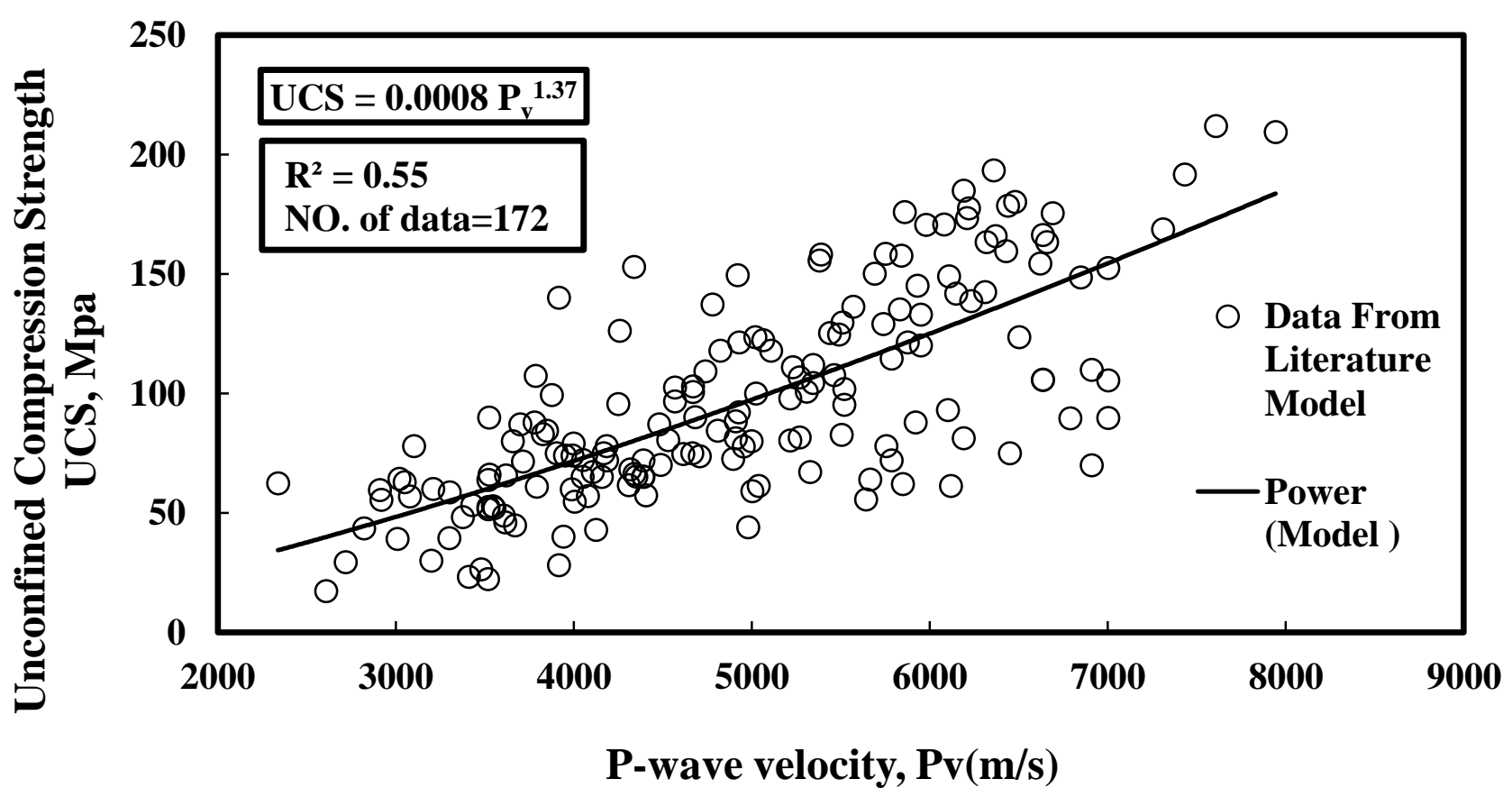

Fig. 1 Unconfined Compression Strength vs P-wave velocity 


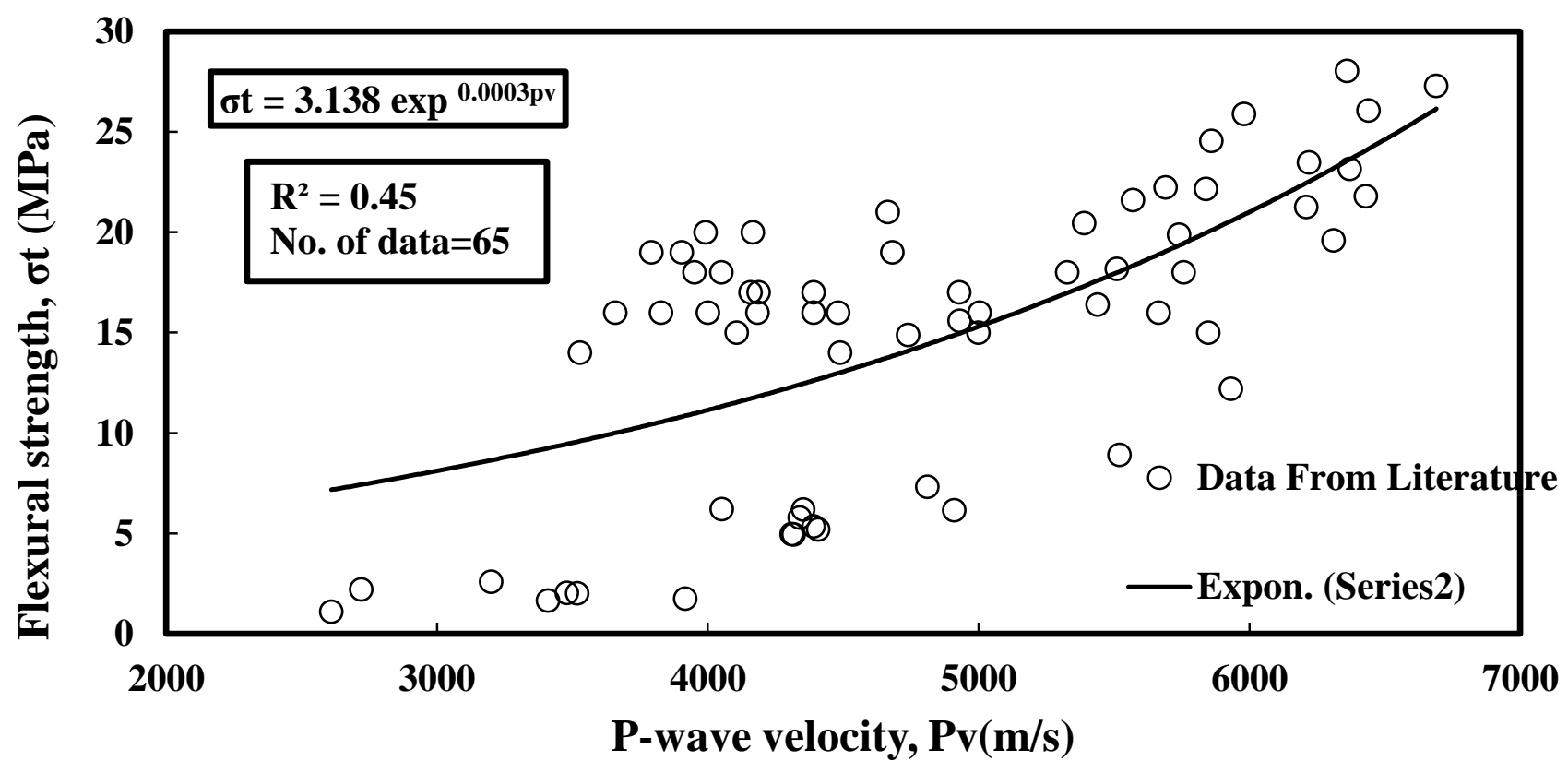

Fig. 2 Flexural strength vs P-wave velocity

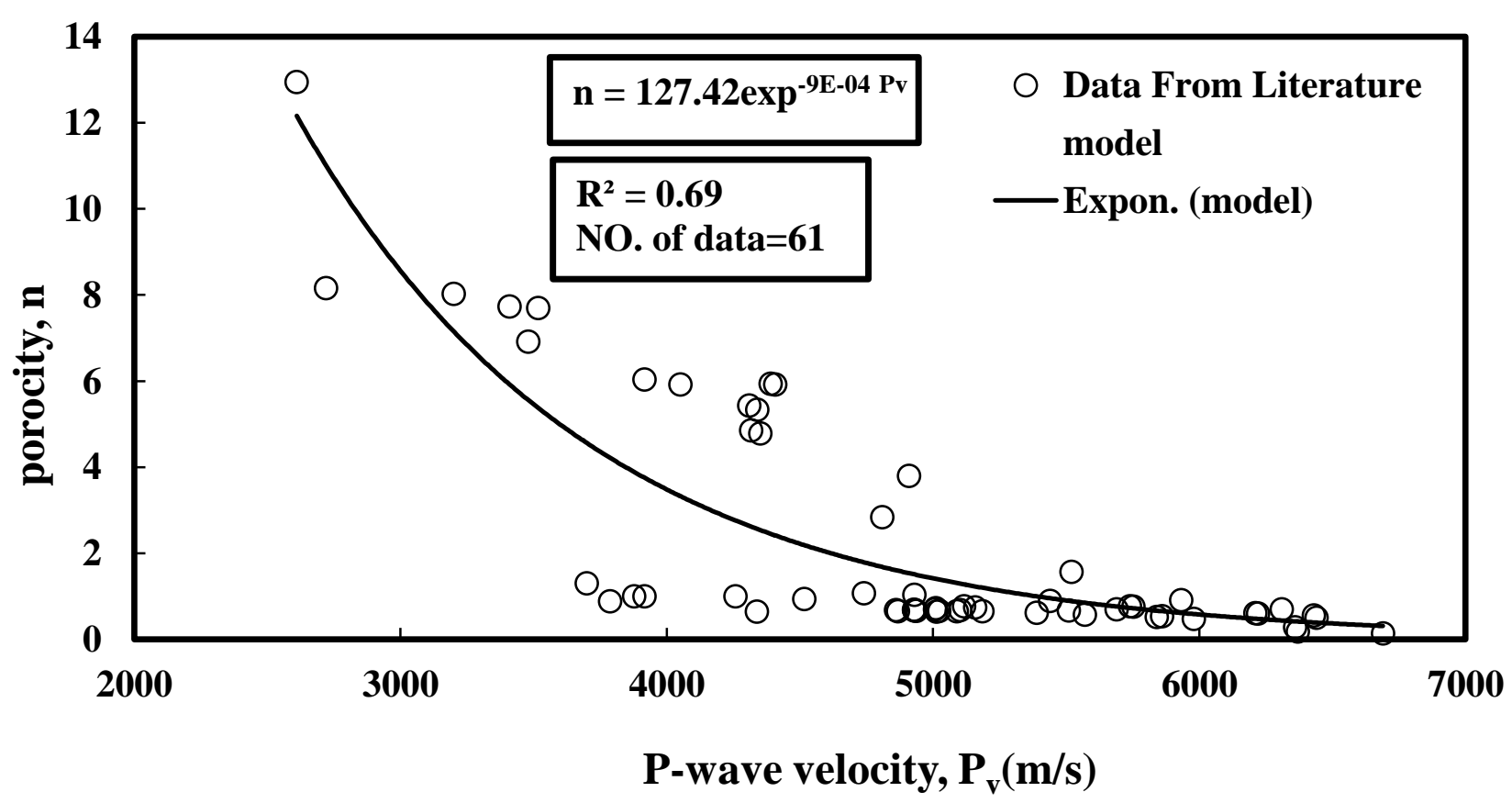

Fig. 3 Flexural strength vs P-wave velocity 


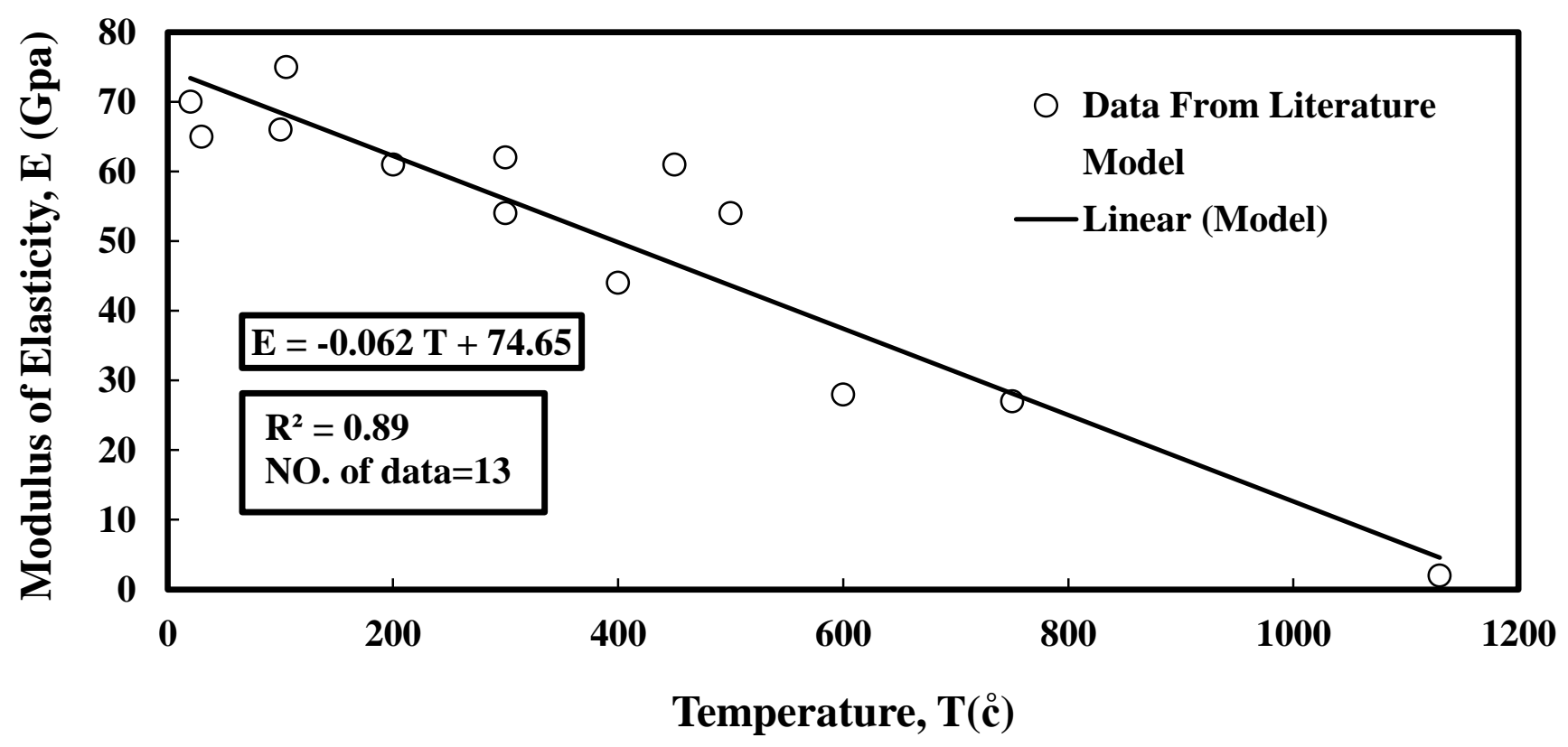

Fig. 4 Modulus of Elasticity vs Temperature

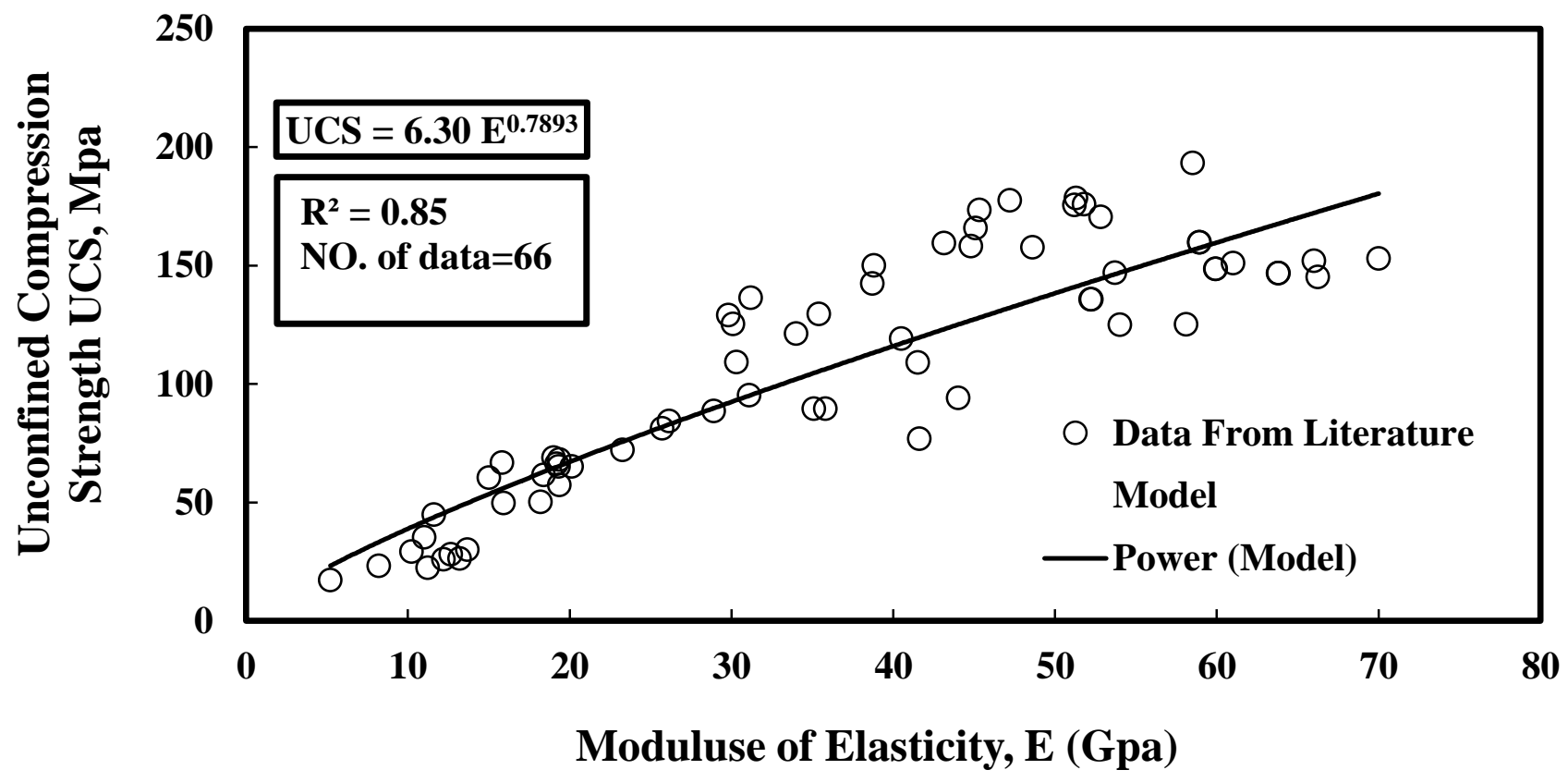

Fig. 5 Unconfined Compression Strength vs Modulus of Elasticity 


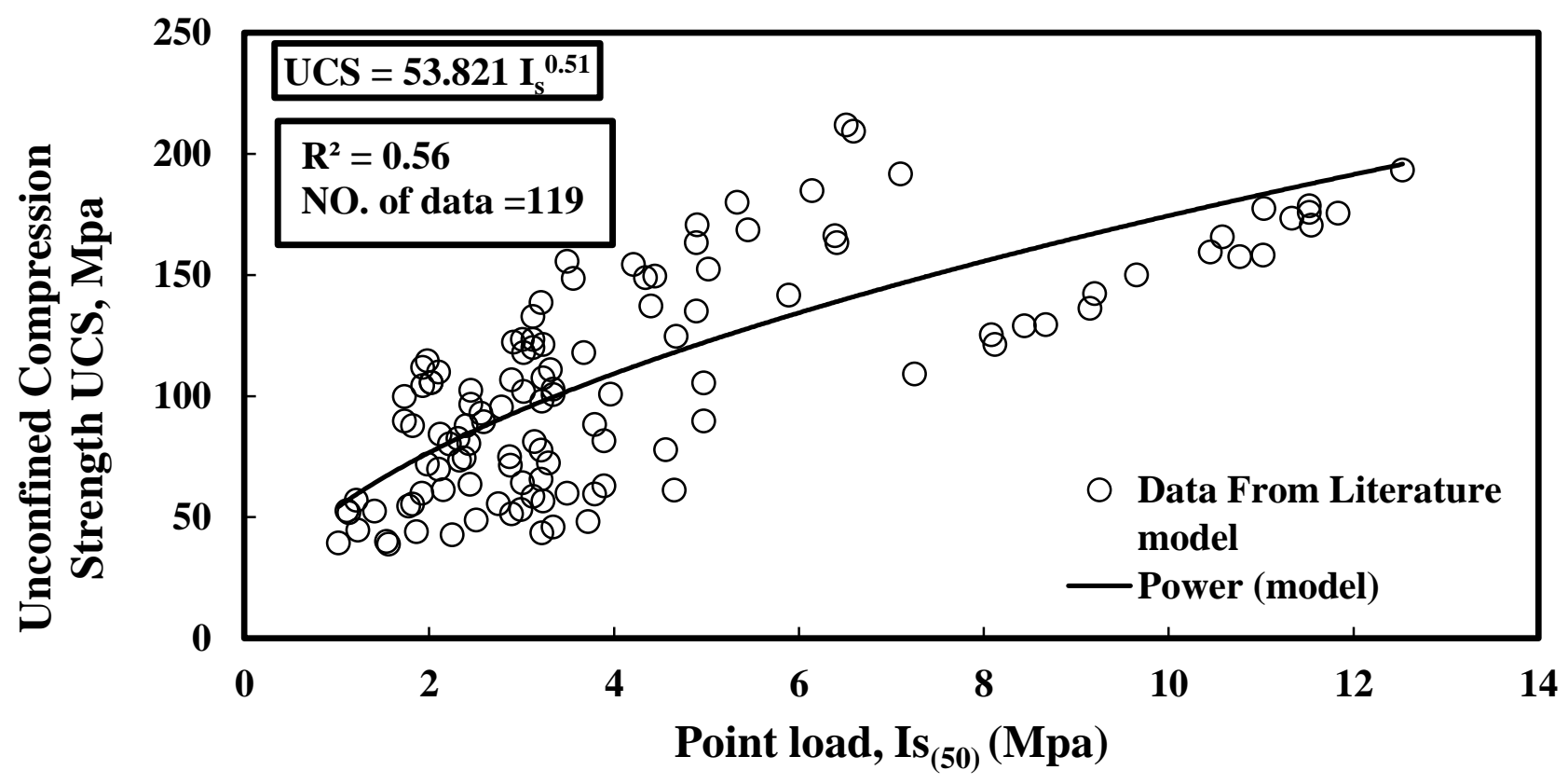

Fig. 6 Unconfined Compression Strength vs Point load

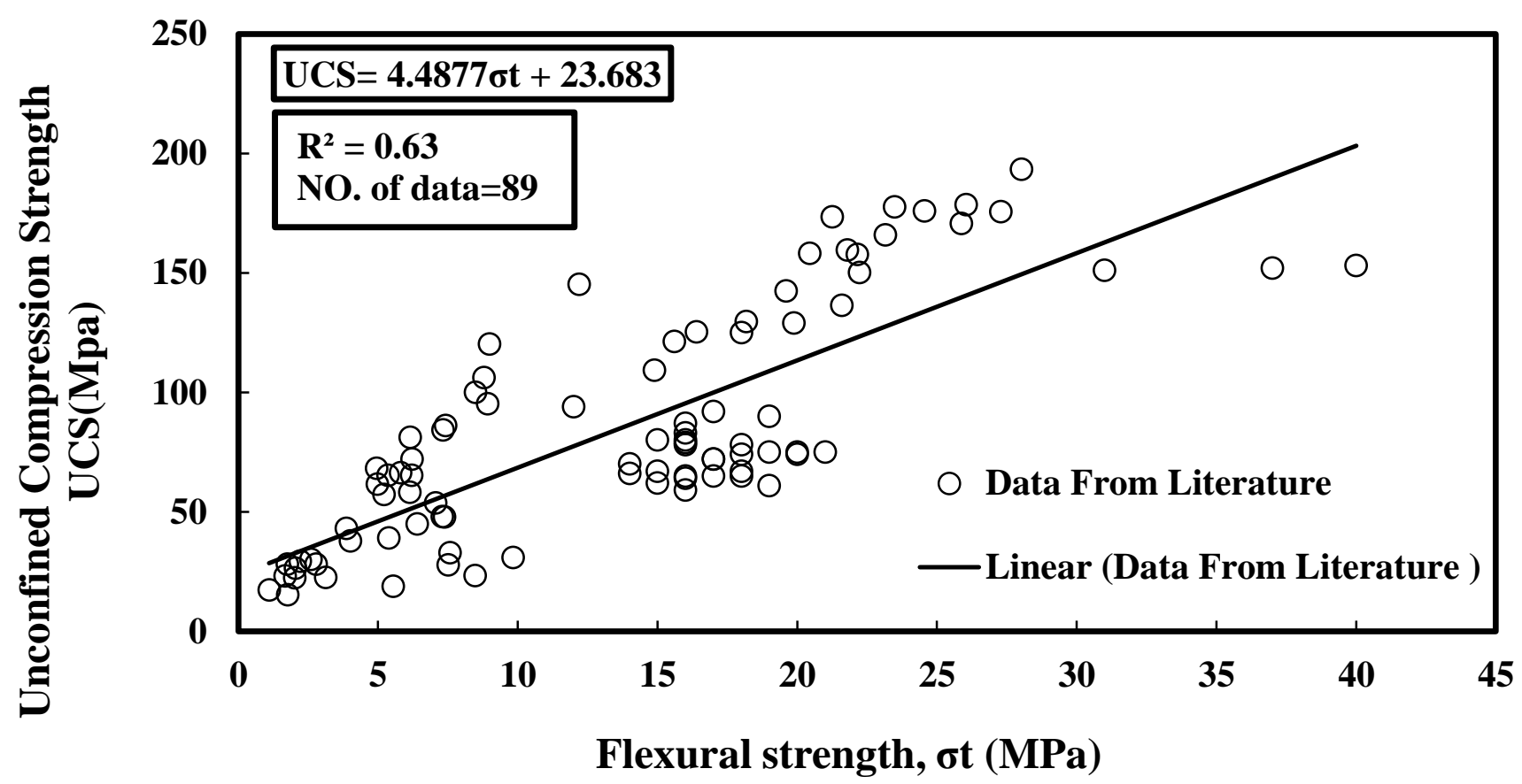

Fig. 7 Unconfined Compression Strength vs Flexural strength 


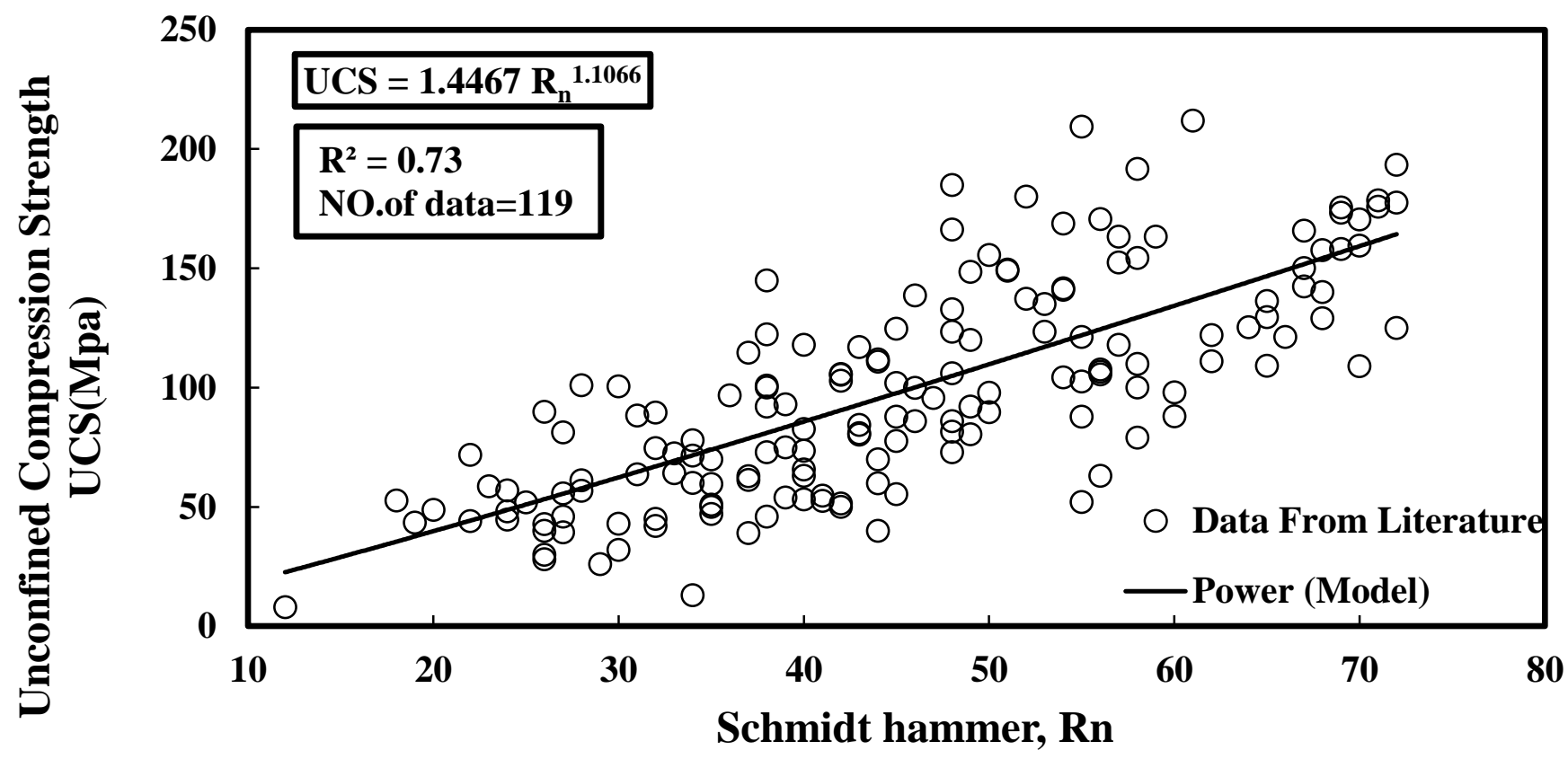

Fig. 8 Unconfined Compression Strength vs Schmidt hammer

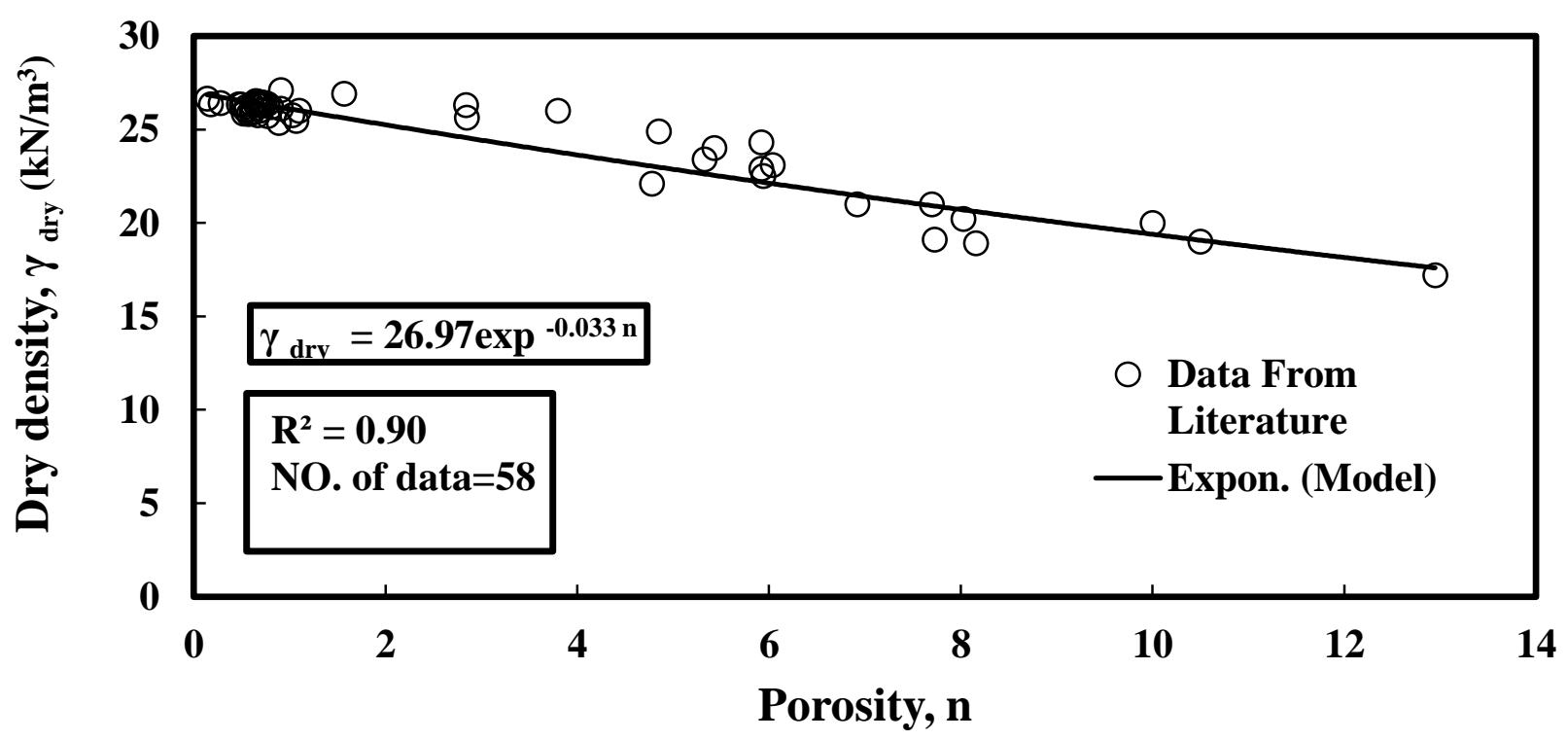

Fig. 9 Dry density vs Porosity 


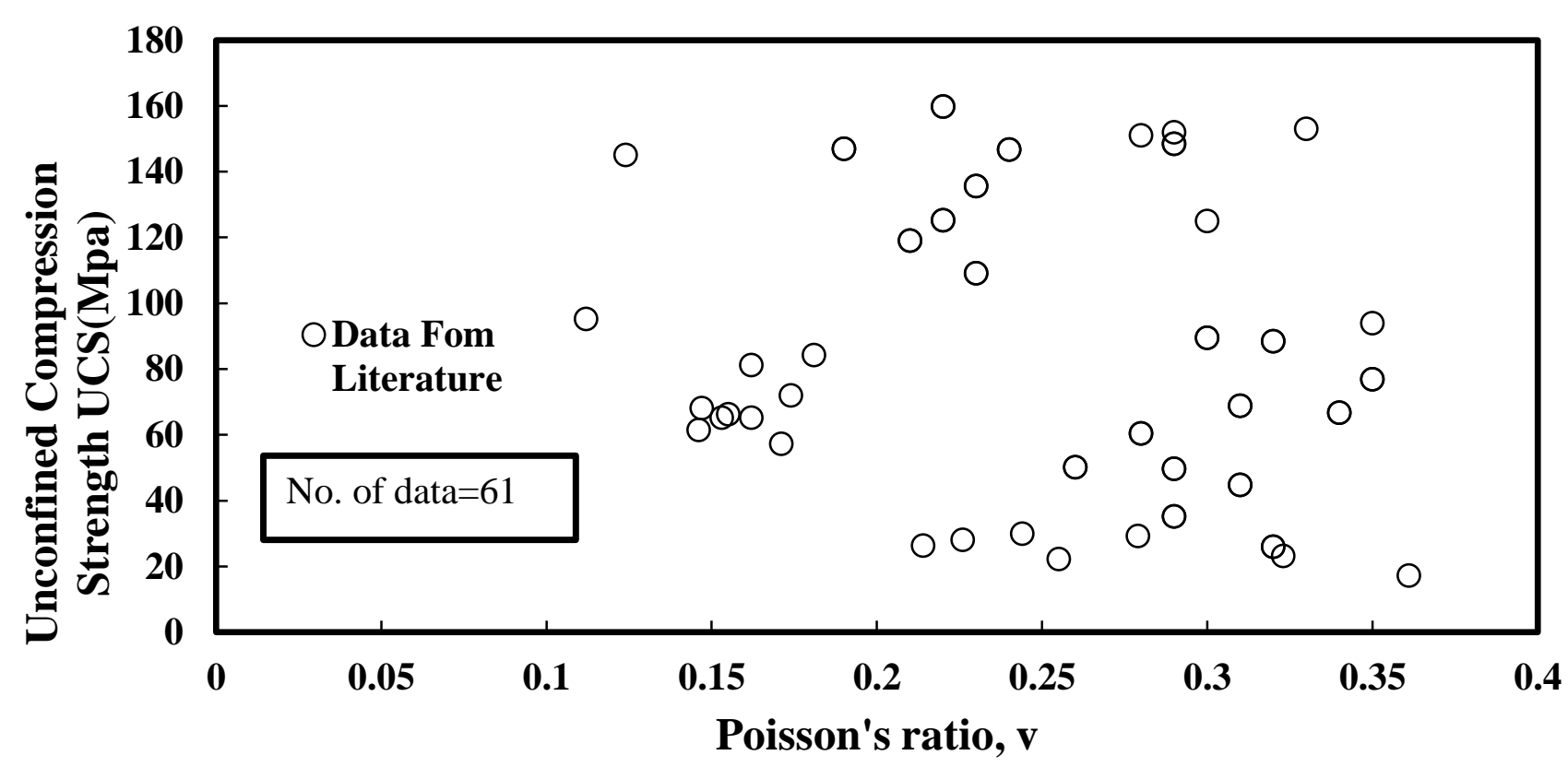

Fig. 8 Unconfined Compression Strength vs Poisson's ratio 